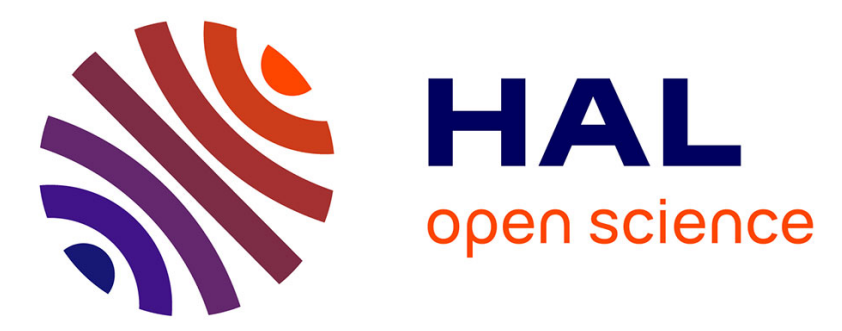

\title{
Involvement of Ca-dependent PKCs in the adaptive changes of $\mu$ opioid pathways to sympathetic denervation in the guinea pig colon
}

C. Giaroni, E. Zanetti, A. Pascale, R. Oldrini, L. Canciani, D. Giuliani, M. Amadio, A.M. Chiaravalli, S. Lecchini, G.M. Frigo

\section{To cite this version:}

C. Giaroni, E. Zanetti, A. Pascale, R. Oldrini, L. Canciani, et al.. Involvement of Ca-dependent PKCs in the adaptive changes of $\mu$ opioid pathways to sympathetic denervation in the guinea pig colon.

Biochemical Pharmacology, 2009, 78 (9), pp.1233. 10.1016/j.bcp.2009.06.107 . hal-00519083

\section{HAL Id: hal-00519083 \\ https://hal.science/hal-00519083}

Submitted on 18 Sep 2010

HAL is a multi-disciplinary open access archive for the deposit and dissemination of scientific research documents, whether they are published or not. The documents may come from teaching and research institutions in France or abroad, or from public or private research centers.
L'archive ouverte pluridisciplinaire HAL, est destinée au dépôt et à la diffusion de documents scientifiques de niveau recherche, publiés ou non, émanant des établissements d'enseignement et de recherche français ou étrangers, des laboratoires publics ou privés. 


\section{Accepted Manuscript}

Title: Involvement of $\mathrm{Ca}^{++}$-dependent PKCs in the adaptive changes of $\mu$ opioid pathways to sympathetic denervation in the guinea pig colon

Authors: C. Giaroni, E. Zanetti, A. Pascale, R. Oldrini, L. Canciani, D. Giuliani, M. Amadio, A.M. Chiaravalli, S.

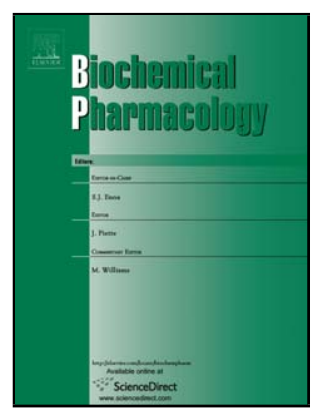

Lecchini, G.M. Frigo

PII:

S0006-2952(09)00600-5

DOI: doi:10.1016/j.bcp.2009.06.107

Reference: BCP 10256

To appear in: $\quad B C P$

Received date: 26-5-2009

Revised date: 29-6-2009

Accepted date: $\quad$ 29-6-2009

Please cite this article as: Giaroni C, Zanetti E, Pascale A, Oldrini R, Canciani L, Giuliani D, Amadio M, Chiaravalli AM, Lecchini S, Frigo GM, Involvement of $\mathrm{Ca}^{++}$-dependent PKCs in the adaptive changes of $\mu$ opioid pathways to sympathetic denervation in the guinea pig colon, Biochemical Pharmacology (2008), doi:10.1016/j.bcp.2009.06.107

This is a PDF file of an unedited manuscript that has been accepted for publication. As a service to our customers we are providing this early version of the manuscript. The manuscript will undergo copyediting, typesetting, and review of the resulting proof before it is published in its final form. Please note that during the production process errors may be discovered which could affect the content, and all legal disclaimers that apply to the journal pertain. 


\title{
Involvement of $\mathrm{Ca}^{++}$-dependent PKCs in the adaptive changes of $\mu$ opioid pathways to sympathetic denervation in the guinea pig colon
}

\section{GIARONI C., ZANETTI E., PASCALE A. , OLDRINI R., CANCIANI L., GIULIANI D., AMADIO M. ${ }^{\S}$, CHIARAVALLI A.M. , LECCHINI S., FRIGO G.M. ${ }^{*}$}

Department of Clinical Medicine, University of Insubria, via O. Rossi 9, I-21100 Varese, Italy

\# Department of Internal Medicine and Therapeutics, piazza Botta 10, I-27100 Pavia, Italy

${ }^{\S}$ Department of Experimental and Applied Pharmacology, Centre of Excellence in Applied Biology, University of Pavia, via Taramelli 14, I-27100 Pavia, Italy

* Surgical Pathology, Department of Human Morphology, via O.Rossi 9, I-21100 Varese, Italy

\author{
Corresponding author: Cristina Giaroni, PhD, Department of Clinical Medicine, Section of \\ Experimental and Clinical Pharmacology, University of Insubria, via O. Rossi 9, I-21100 \\ Varese, Italy. \\ Tel: ++39 0332 217412; fax: ++390332 217119 \\ E-mail address: cristina.giaroni@uninsubria.it
}




\section{Abstract}

In the guinea pig colon, chronic sympathetic denervation entails supersensitivity to inhibitory $\mu$-opioid agents modulating cholinergic neurons. The mechanism underlying such adaptive change has not yet been unravelled, although protein kinase C (PKC) may be involved. A previous study indirectly demonstrated that activation of $\mu$-opioid receptors on myenteric neurons facilitates PKC activity. Such coupling may counteract the inhibitory action of $\mu$ opioid agents on acetylcholine overflow, since $\mathrm{PKC}$, per sè, increases this parameter. After chronic sympathetic denervation such restraint abates, representing a possible mechanism for development of supersensitivity to $\mu$-opioid agents. In the present study, this hypothesis was further investigated. After chronic sympathetic denervation, $\mathrm{Ca}^{++}$-dependent $\mathrm{PKC}$ activity was reduced in colonic myenteric plexus synaptosomes. The $\mu$-opioid agent, DAMGO, increased $\mathrm{Ca}^{++}$-dependent PKC activity in synaptosomes obtained from normal, but not from denervated animals. In myenteric synaptosomes obtained from this experimental group, protein levels of $\mathrm{Ca}^{++}$-dependent PKC isoforms $\beta \mathrm{I}, \beta \mathrm{II}$ and $\gamma$ decreased, whereas $\alpha$ levels increased. In wholemount preparations, the four $\mathrm{Ca}^{++}$-dependent PKC isoforms co-localized with $\mu$-opioid receptors on subpopulations of colonic myenteric neurons. The percentage of neurons staining for PKC $\beta I I$, as well as the number of $\mu$-opioid receptor-positive neurons staining for PKC $\beta I I$, decreased in denervated preparations. The same parameters related to PKC $\alpha, \beta I$ or $\gamma$ remained unchanged. Overall, the present data strengthen the concept that $\mu$-opioid receptors located on myenteric neurons are coupled to $\mathrm{Ca}^{++}$-dependent PKCs. After chronic sympathetic denervation, a reduced efficiency of this coupling may predominantly involve PKC $\beta I I$, although also PKC $\beta I$ and $\gamma$, but not PKC $\alpha$, may be implicated. 
1

2

Keywords: $\mathrm{Ca}^{++}$-dependent PKC, $\mu$ opioid receptor, sympathetic denervation, changes in sensitivity, myenteric plexus. 


\section{Introduction}

Endogenous opioid peptides and opioid drugs are known to mediate a variety of biological processes, including stress response, immunity, analgesia, motor activity and autonomic functions, such as gastrointestinal motility and secretion [1, 2]. Biochemical transduction of these effects involves molecular binding of the drug to opioid receptors, which belong to the G protein-coupled receptor family. Activation of opioid receptors principally results in attenuating neuronal activity by inhibiting neurotransmitter release and changing neuronal excitability by pre- and postsynaptic mechanisms, respectively [3, 4].

A number of studies have demonstrated that a functional interaction may occur between opioid receptors and other inhibitory $\mathrm{G}$ protein-coupled receptors, which may have importance in the development of responses after both acute and chronic exposure to opiates. One of the most studied interplay involves opioid receptor and $\alpha_{2}$-adrenoceptor pathways. Such interaction may be antagonistic or synergistic. Several studies have demonstrated that acute activation of one receptor pathway may lead either to attenuation or potentiation of the other [5-10]. Functionally related $\alpha_{2}$-adrenoceptor and opioid receptor pathways may be involved in adaptive changes occurring in excitable cells when a net stimulus is chronically changed. Tolerance and dependence to the effect of opiates may represent an example of adaptive sensitivity change leading to altered function not only of opioid but also of a variety of other neuronal systems, including $\alpha_{2}$-adrenoceptors, in the central nervous system and peripherally $[11,12]$. Several reports have described the occurrence of changes in $\alpha_{2}-$ adrenoceptor sensitivity after chronic morphine treatment in the enteric nervous system (ENS) [13-15], which represents a complex and integrative neuronal network suitable for the study of neuronal plasticity [16]. Adaptive changes involving inhibitory $\mu$-opioid receptor and $\alpha_{2}$ adrenoceptor pathways have been documented also after chronic ablation of the 
sympathoadrenergic pathway innervating the guinea pig distal colon. In these experimental conditions, reduced sensitivity to $\alpha_{2}$-adrenergic agonists and enhanced sensitivity to $\mu$-opioid agents developed on both acetylcholine overflow and peristalsis, in order to maintain intestinal motility under an homeostatic control [17]. Indeed, there are reports in the literature suggesting that after extrinsic denervation, an intrinsic pathway may take over the function of the suppressed extrinsic input, allowing restoration of the intestinal function [16]. More generally, the occurrence of rearrangements of intrinsic enteric neuronal circuitries after extrinsic denervation may help to understand the occurrence of functional abnormalities/functional recovery in patients after injuries or surgical procedures [16].

From a molecular viewpoint, the functional interplay between opioid receptors and $\alpha_{2}-$ adrenoceptors has been suggested to depend upon several factors, including changes in transmitter release, alterations at the receptor level and in the intracellular signalling pathways coupled to receptor activation $[12,18,19]$. At this latter regard, a key role in the modulation of intracellular responses is played by protein kinase $\mathrm{C}(\mathrm{PKC})$. $\mathrm{PKC}$ is a family of at least 11 isoenzymes, some of which are highly expressed at a neuronal level [20-22]. Among the different PKC isoforms, $\mathrm{Ca}^{++}$-dependent or conventional PKCs $\alpha, \beta \mathrm{I}, \beta \mathrm{II}$ and $\gamma$, are fully activated by calcium ions and by a transient increase in diacylglycerol and/or arachidonic acid and metabolites, which are formed through various pathways after breakdown of membrane phospholipids by different phospholipases, including phospholipase C (PLC), phospholipase D (PLD) and phospholipase $\mathrm{A}_{2}\left(\mathrm{PLA}_{2}\right)$ [23].

The ability of opioid receptors to activate phosphoinositide pathways and, consequently, PKC, has been demonstrated in different experimental models [24-25]. In addition, PKC may participate in the cellular and synaptic adaptation mediating opioid dependence [26]. Recently, functional and biochemical evidence has been provided to suggest that a reduced efficiency of $\mathrm{Ca}^{++}$-dependent PKC, in the myenteric plexus of the guinea pig colon after 
chronic sympathetic denervation, might contribute to the development of supersensitivity to $\mu$ opioid agonists in these experimental conditions [27].

To shed more light on the possible link between PKC and the development of adaptive changes to $\mu$-opioid agonists in the myenteric plexus of the guinea pig colon after chronic sympathetic denervation, in the present study, we evaluated the effect of the $\mu$-opioid agonist, DAMGO, on $\mathrm{Ca}^{++}$-dependent PKC activity in myenteric plexus synaptosomes. In the same experimental model, the abundance of the different $\mathrm{Ca}^{++}$-dependent $\mathrm{PKC}$ isoforms has been investigated by Western blotting. Finally, the possible co-localization of $\mathrm{Ca}^{++}$-dependent PKCs with $\mu$-opioid receptors has been explored by immunohistochemistry on colonic wholemounts preparations obtained from normal and denervated animals.

\section{Methods}

\subsection{Animals}

Male Dunkin-Hartley guinea pigs (Harlan Italy, Correzzana, Monza Italy) weighing between 300 and $350 \mathrm{~g}$ were housed in groups of four under controlled environmental conditions (temperature $22 \pm 2^{\circ} \mathrm{C}$; relative humidity $60-70 \%$ ) with free access to a standard diet and water, and were maintained at a regular 12/12-h light/dark cycle. Animals were sacrificed by decapitation and the colon was rapidly excised and rinsed with an ice-cold Tyrode's solution (composition [mM]: $137 \mathrm{NaCl} ; 2.68 \mathrm{KCl} ; 1.8 \mathrm{CaCl}_{2} .2 \mathrm{H}_{2} \mathrm{O} ; 2 \mathrm{MgCl}_{2} ; 0.47 \mathrm{NaH}_{2} \mathrm{PO}_{4} ; 11.9$ $\mathrm{NaHCO}_{3} ; 5.6$ glucose). Principles of good laboratory animal care were followed and animal experimentation was in compliance with specific national (DL $116 \mathrm{GU}$ suppl 40, 18 febbraio 1992; Circolare n 8 GU 14 luglio 1994) and international laws and regulations (EEC Council Directive 86/609, OJL 358,1, dec 12 1987). 


\subsection{Chronic sympathetic denervation}

Chronic sympathetic denervation was obtained by surgical removal of the inferior mesenteric ganglion and freezing of the periarterial plexus at least 6 days before the experiments as described by Mazzanti et al. [28], with modifications. Briefly, animals were anesthetized with sevofluorane (Sevorane ${ }^{\circledR}$, Abbott, Aprilia Italy, 1.5-4.0\% with oxygen). The intestine was exteriorized by a midline laparatomy and kept on warm $0.9 \%$ sterile saline-soaked cotton gauze to reduce dehydration and cooling. The terminal part of the colon was exposed and the inferior mesenteric ganglion was identified and removed surgically by mans of fine forceps. Successively, a segment of the periarterial plexus $(2-3 \mathrm{~mm})$ along the inferior mesenteric artery just below the ganglion, was frozen with $\mathrm{N}_{2} \mathrm{O}$ for 3 min. The abdominal wall was then sutured and the animals were sacrificed at least 6 days after the surgical intervention Antibiotic prophylaxis was performed by injecting ampicillin $100 \mathrm{mg} / \mathrm{kg}$ of body weight (Amplital ${ }^{\circledR}$, Pfizer Italia, Latina, Italy) daily for the first 4 days after surgery.

\subsection{Myenteric plexus enriched synaptosomal preparation}

Enriched synaptosomal fractions of myenteric plexus neurons were obtained from colonic preparations consisting of the external longitudinal muscle layer segments with attached myenteric plexus (LM/MP) after successive centrifugations as already described [29]. Briefly, LM/MP preparations pooled from 3-5 animals were homogenized in ice-cold 3-Nmorpholinopropanesulfonic acid (MOPS)-sucrose isolation buffer [containing $25 \mathrm{mM}$ MOPS, $10 \mathrm{mM} \mathrm{MgCl} 2,8 \% \mathrm{w} / \mathrm{v}$ sucrose, $1 \mathrm{mM}$ phenylmethylsulfonyl fluoride (PMSF) and $25 \mu \mathrm{g} / \mathrm{ml}$ leupeptin, $\mathrm{pH}$ 7.4]. The crude homogenate was centrifuged in two steps at $800 \mathrm{x}$ g for $10 \mathrm{~min}$. 
The supernatants were collected and centrifuged again at $3500 \mathrm{xg}$ for $10 \mathrm{~min}$. The supernatant was then filtered (pore size $11 \mu \mathrm{m}$; Millipore, Billerica, MA) and centrifuged at high speed $(120,000 \mathrm{x}$ g) for $60 \mathrm{~min}$. The resulting pellet was re-suspended and centrifuged again at $10,000 \mathrm{x} \mathrm{g}$ for $10 \mathrm{~min}$ to obtain an enriched synaptosomal pellet. Some synaptosomal preparations were obtained to measure $\mathrm{Ca}^{++}$-dependent $\mathrm{PKC}$ activity. In this case, LM/MP preparations were perfused at a rate of $1 \mathrm{ml} \cdot \mathrm{min}^{-1}$ with Tyrode's solution, gassed with $\mathrm{O}_{2^{-}}$ $\mathrm{CO}_{2}(95 \%-5 \%)$ and maintained at $36.5^{\circ} \mathrm{C}$ in $3 \mathrm{ml}$ organ baths. LM/MPs were allowed an equilibration period of $40 \mathrm{~min}$, then either DAMGO $(0.1 \mu \mathrm{M})$ and/or CTAP $(1 \mu \mathrm{M})$ were added to the superfusion medium for $20 \mathrm{~min}$. The concentration of $0.1 \mu \mathrm{M}$ DAMGO was chosen as it corresponds to the maximal dose of agonist inhibiting acetylcholine overflow from the guinea pig colon, obtained from both normal and denervated animals, as previously described [17]. After exposure to test drugs, LM/MPs were collected to obtain enriched synaptosomal membranes.

The enriched myenteric synaptosomal fraction was successively suspended in a protein extraction reagent, T-PER (Pierce, Rockford, Il) containing a commercial protease inhibitor cocktail (Complete $^{\circledR}$, Roche, Manheim Germany), incubated on ice for $15 \mathrm{~min}$, sonicated and centrifuged at 7,000 $\mathrm{x}$ g for $5 \mathrm{~min}$. Aliquots of the sample were used for protein assay by means of Bradford's micromethod [30]. The remaining was processed for either $\mathrm{Ca}^{++}-$ dependent PKC activity assay or Western-blot analysis of PKC-dependent isoforms. The integrity of synaptosomes has been demonstrated by electron microscopy.

\section{$2.2 \mathrm{Ca}^{++}$-dependent PKC activity assay}


$\mathrm{Ca}^{++}$-dependent PKC activity was assessed as previously described [31]. Briefly, $2 \mu \mathrm{g}$ of proteins extracted from myenteric plexus enriched synaptosomal preparations were incubated at $37^{\circ} \mathrm{C}$ in $100 \mu \mathrm{l}$ final volume of a buffer containing $3 \mu \mathrm{mol}$ Tris- $\mathrm{HCl}(\mathrm{pH} 7.5), 0.8 \mu \mathrm{mol}$ of magnesium acetate and $1 \mu \mathrm{g}$ of Pep $\alpha$ (Celbio, Milan, Italy), as a kinase-specific substrate. The reaction was started by adding $50 \mu \mathrm{M}\left[\gamma^{32} \mathrm{P}\right] \mathrm{ATP}(0.45 \mu \mathrm{Ci} /$ sample; specific activity 3,000 Ci/mmol; Amersham Pharmacia Biotech, Cologno Monzese, Italy). Basal activity was measured in the presence of $0.1 \mu \mathrm{mol}$ EGTA, whereas stimulated activity was evaluated in the presence of $0.1 \mu \mathrm{mol} \mathrm{CaCl} 2$ (in place of EGTA), $10 \mu \mathrm{g}$ of phosphatidylserine and $1 \mu \mathrm{g}$ of diolein. The reaction was stopped after 5 minutes by spotting $25 \mu$ of the sample onto phosphocellulose paper P-81 (Whatman, GE Healthcare, Milan, Italy), adding $25 \mu 1$ of $0.6 \%$ (vol/vol) $\mathrm{H}_{3} \mathrm{PO} 4$ to the spot, and washing the paper with tap water. Radioactivity retained by the phosphocellulose was determined by liquid scintillation counting using Formula 989 (NEN, Cologno Monzese, Italy). Specific PKC activity was evaluated as the difference between stimulated and basal activities and expressed as nmol/min/ $\mathrm{mg}$ protein.

\subsection{Western blotting analysis of $\mathrm{Ca}^{++}$-dependent PKC isoforms}

Aliquots of the protein fraction obtained from myenteric plexus enriched synaptosomal preparations were diluted in 2x sodium dodecyl-sulphate (SDS) protein gel loading solution (Quality Biological, MD), boiled for 5 minutes, separated on 12\% SDS-polyacrylamide gel electrophoresis (SDS-PAGE) and electroblotted to nitrocellulose transfer membranes (GE Healthcare, Milan, Italy) as previously described [32]. Membranes were then incubated overnight at $4{ }^{\circ} \mathrm{C}$ with primary antisera (Table 1) optimally diluted with a TBS-T solution [composition: $10 \mathrm{mM}$ Tris, $100 \mathrm{mM} \mathrm{NaCl}, 0.1 \%$ Tween $20, \mathrm{pH} 7.5$ ] containing $6 \%$ non-fat 
milk. After washing with TBS-T for 30 min, the horseradish peroxidase-conjugated secondary antibodies were diluted in $6 \%$ milk in TBS-T buffer and incubated at room temperature for 1 hour at a dilution of 1:10000 and 1:5000 for PKC $\alpha$ and PKC $\beta I I$, respectively, and of 1:2000 for PKC $\beta \mathrm{I}, \mathrm{PKC} \gamma$ and $\alpha$-tubulin. Nitrocellulose membrane signals were detected by enhanced chemiluminescence technique as indicated by the manufacturer (Amersham Pharmacia Biotech, Cologno Monzese, Italy). Sample pairs, obtained from normal and sympatheticallydenervated animals were electrophoresed, blotted in parallel, and exposed to the same film (Hyperfilm ECL, GE Healthcare, Milan, Italy). Signal intensity was quantified by densitometric analysis using the NIH image software 1.61 (downloadable at http://rsb.info.nih.gov/nih-image). In each membrane $\alpha$-tubulin, a cytoskeletal protein, was monitored and used as protein loading control. $\alpha$-tubulin immunoreactivity levels were found unchanged after chronic sympathetic denervation $(-0.39 \pm 2.45 \%, \mathrm{n}=26$ vs. normal preparations). Experiments were performed at least three times for each different preparation. The effect of sympathetic denervation on PKC levels was expressed as percentage variation versus the normal preparations. Prestained molecular mass markers (250-10 kDa range, Precision Plus Protein Standards, BioRad, Hercules, CA) were used to determine the molecular weight (MW) of the immunoreactive bands.

\subsection{Immunohistochemistry}

Segments of the guinea pig distal colon were fixed for 4 hours at room temperature in $4 \%$ formaldehyde plus $0.2 \%$ picric acid in $0.2 \mathrm{M}$ sodium phosphate-buffer ( $\mathrm{pH}$ 7.4). Preparations were cleared of fixative with $3 \times$ 10-min washes in phosphate-buffered saline (PBS: $0.14 \mathrm{M}$ $\mathrm{NaCl}, 0.003 \mathrm{M} \mathrm{KCl}, 0.015 \mathrm{M} \mathrm{Na}_{2} \mathrm{HPO}_{4}, 0.0015 \mathrm{M} \mathrm{KH}_{2} \mathrm{PO}_{4}, \mathrm{pH}$ 7.4). Fixed tissue was stored at $4^{\circ} \mathrm{C}$ in PBS containing $0.05 \%$ 2-(ethylmercuriomercapto)benzoic acid (thimerosal). LM/MP 
whole-mount colonic preparations were prepared by removing the mucosa, submucosa and circular muscle layers, according to the method of Toole et al. [33], with modifications. Briefly, preparations were exposed for $1 \mathrm{~h}$ to a PBS solution containing 1\% Triton X-100 and 5\% normal horse serum (NHS) (Euroclone, Celbio, Milan, Italy), to permeabilise the tissue and to block non-specific binding sites. To perform double labeling, primary antibodies were exposed during consecutive incubation times. Firstly, primary antibodies raised against $\mathrm{Ca}^{++}$dependent PKCs, optimally diluted, were added overnight at room temperature (RT). Samples were washed ( $3 \times 10$-min) in PBS, then two successive $1 \mathrm{~h}$ incubations with a goat anti-mouse biotinylated secondary antibody (1:400, Caltag Lab, Burlingame, CA) and with strepatividin Cy3 (1: 400 Caltag Lab) followed at RT. The second primary antibody raised against $\mu$-opioid receptor was then added and incubated overnight at RT . After $3 \times 10$-min washes in PBS, incubation with Alexa Fluor $4888^{\circledR}$ labelled donkey anti-rabbit secondary antibody (Molecular Probes, Eugene, OR) followed for $2 \mathrm{~h}$ at RT. Preparations were given $3 \times 10$-min washes, in PBS, before being mounted onto glass slides, using a commercially available mounting medium with DAPI (Vectashield ${ }^{\circledR}$, Vector Lab., Burlingame, CA). All primary antibodies used were commercially available, whose features and working dilutions are listed in Table 1. The proportions of neurons in which antigen immunoreactivity was co-localized were determined by examining fluorescently labelled, double-stained, preparations. Neuron cohort size was $59.74 \pm 0.36, \mathrm{n}=31$ neurons and data were collected from preparations obtained from at least three animals. The number of neurons immunoreactive for either $\mathrm{PKCs} \mathrm{Ca}^{++}$dependent isoforms or $\mu$-opioid receptor was calculated as a percentage of the total number of neurons. Photographs were taken using a Hamamatsu C5985 CDD camera (Hamamatsu Photonics, Hamamatsu, Japan) attached to a Leica microscope DMRA2 (Leica, Wetzlar Germany) and pictures were processed using Adobe-Photoshop CS2.0 software. 


\subsection{Statistical analysis}

Data are presented as mean \pm SEM. $n$ indicates the number of experiments. For statistical analysis the GraphPad Instat statistical package (version 4.01 GraphPad software, San Diego, CA, USA) was used. The data were analyzed either by one sample $t$ test, Student's $t$-test or by analysis of variance (ANOVA) followed, when significant, by an appropriate post hoc comparison test (Dunnett's Multiple Comparisons) as indicated either in the text or in the legends. Differences were considered statistically significant when $p$ values $\leq 0.05$.

\subsection{Drugs and materials}

[H-D-Phe-Cys-Tyr-D-Trp-Arg-Thr-Pen-Thr-NH2] (CTAP) and [D-Ala2,N-Me-Phe4,Gly-ol5]enkephalin (DAMGO), 3-N-morpholinopropanesulfonic acid (MOPS), phenylmethylsulfonyl fluoride (PMSF) and 2-(ethylmercuriomercapto)benzoic acid (thimerosal) were purchased from Sigma-Aldrich (Milan, Italy). All other reagents were purchased either from SigmaAldrich or from BioRad.

\section{Results}

3.1 Effect of DAMGO on $\mathrm{Ca}^{++}$-dependent PKC activity in myenteric synaptosomes of the guinea pig distal colon obtained from normal and sympathetically denervated animals

$\mathrm{Ca}^{++}$-dependent PKC activity was significantly lower in synaptosomal preparations obtained from sympathetically-denervated animals $(-32.63 \pm 5.99 \%, \mathrm{n}=8, \mathrm{p}<0.01$ by one sample $\mathrm{t}$ test $)$ than in those obtained from normal animals. 
In normal preparations, $\mathrm{Ca}^{++}$-dependent $\mathrm{PKC}$ activity significantly increased in the presence of the $\mu$-opioid agonist, DAMGO $0.1 \mu \mathrm{M}(+50.78 \pm 7.61 \%, \mathrm{n}=9$; $\mathrm{p}<0.001$ vs control by one sample $t$ test), and this facilitatory effect was abolished by the selective antagonist CTAP $(1 \mu \mathrm{M} ; 0.56 \pm 14.47 \%, \mathrm{n}=9 \mathrm{p}<0.01$ vs DAMGO treated preparations) (Fig. 1). In normal preparations, CTAP, per se, did not influence $\mathrm{Ca}^{+++}$-dependent PKC activity $(+12.75 \pm 11.07 \%$, $\mathrm{n}=8, \mathrm{p}>0.05$ vs control preparations by one sample $\mathrm{t}$ test).

After chronic sympathetic denervation, DAMGO did not influence $\mathrm{Ca}^{++}$-dependent PKC activity in myenteric plexus synaptosomes neither in the absence nor in the presence of CTAP $(-10.67 \pm 8.19 \%, \mathrm{n}=6$ and $4.60 \pm 2.73 \%, \mathrm{n}=5$, respectively $\mathrm{p}>0.05$ vs control and $\mathrm{p}<0.01$ and $\mathrm{p}<0.05$ vs DAMGO-treated normal preparations) (Fig. 1).

\subsection{Effect of chronic sympathetic denervation on immunoreactivity levels of $\mathrm{Ca}^{++}$-dependent} PKC isoforms in myenteric plexus synaptosomes

Western blotting analyses of PKC $\alpha$, PKC $\beta I$ and PKC $\gamma$ revealed one band at about $80 \mathrm{kDa}$ in guinea pig myenteric plexus synaptosomes, as already demonstrated for pan PKC [27].

The intensity of the immunoreactive band corresponding to PKC $\alpha$ increased in synaptosomal preparations obtained from sympathetically-denervated animals with respect to the one observed in normal animals $(+41.63 \pm 13.69 \%, \mathrm{n}=8, \mathrm{p}<0.05$, by one sample $\mathrm{t}$ test) (Fig. 2). In synaptosomes obtained from sympathetically-denervated animals, immunoreactivity levels relative to PKC $\beta \mathrm{I}, \mathrm{PKC} \beta \mathrm{II}$ and $\mathrm{PKC} \gamma$ were significantly lower with respect to those observed in normal animals (PKC $\beta \mathrm{I}:-41.42 \pm 5.64 \%, \mathrm{n}=6, \mathrm{p}<0.001$; PKC $\beta \mathrm{II}:-32.57 \pm 14.24 \%$, $\mathrm{n}=7, \mathrm{p}<0.05 ; \mathrm{PKC} \gamma:-43.40 \pm 9.93 \%, \mathrm{n}=5, \mathrm{p}<0.05$, by one sample $\mathrm{t}$ test) (Fig. 2). 


\subsection{Distribution of $\mu$-opioid receptor and $\mathrm{Ca}^{++}$-dependent $\mathrm{PKC}$ isoforms immunoreactivity in} the guinea pig distal colon obtained from normal and sympathetically denervated animals

In guinea pig distal colon whole-mount preparations obtained from both normal and denervated animals, $\mu$-opioid receptor immunoreactivity was localized at the cell-surface membrane and in the cytoplasm of myenteric plexus neurons located both within myenteric ganglia and along interganglionic strands (Fig. 3, panels A, C, E, G). $\mu$-opioid receptor positive neurons had morphological characteristics of Dogiel type I neurons, with fusiform cell body, several thick dendrites and a long axonal process. $\mu$-opioid receptor immunoreactivity was also detected in neuronal fibers within the myenteric plexus, in interganglionic strands and in the external muscle layer. Support cells situated adjacent to myenteric plexus structures, morphologically identified as interstitial Cajal cells (ICC) with an elongated tapering nuclear region and bilateral extensions, resulted immunoreactive to $\mu$ opioid receptor antiserum. In normal animals, the percentage of neurons positive to $\mu$-opioid receptor was $24.81 \pm 1.62 \%(\mathrm{n}=16)$ and remained unchanged after chronic sympathetic denervation $(27.14 \pm 2.49 \%, \mathrm{n}=15 P>0.05)$.

PKC $\alpha$ immunoreactivity was found in the cytoplasm of myenteric neurons retaining a fusiform shape, both in normal (Fig 3 panel B) and sympathetically denervated preparations (not shown). Neuronal fibers along interganglionic connectivities and in the external muscle layer were positively marked with PKC $\alpha$ antibody. Strong staining was found in the cytoplasm, plasma membrane and processes of enteric glial cells. Furthermore, sparse single cells, recognized on the basis of their morphology and location, as polymorphonucleated cells, displayed immunoreactivity for PKC $\alpha$. The percentage of PKC $\alpha$ positive neurons in denervated preparations was not significantly different from the value obtained in normal 
preparations $(17.68 \pm 0.95 \%, \mathrm{n}=5 ; 18.92 \pm 1.20 \%, \mathrm{n}=3$, respectively, $\mathrm{P}>0.05)$ (Fig. 4 panel A). After chronic sympathetic denervation, the percentage of $\mu$-opioid receptor-positive neurons immunoreactive for $\mathrm{PKC} \alpha(28.97 \pm 2.19 \%, \mathrm{n}=3)$ was not significantly different $(\mathrm{P}>0.05)$ from the value obtained in normal preparations $(28.89 \pm 4.44 \%, n=4)$ (Fig. 4 panel B).

In preparations obtained from both normal and denervated animals, PKC $\beta \mathrm{I}$ immunoreactivity was detected as a "speckled" labelling of plasma membranes and cytoplasm of myenteric neurons (Fig 3, panel D). Enteric glial cells displayed a faint staining for PKC $\beta I$. Fibroblasts in the muscle layer and blood vessels were also labelled for PKC $\beta$ I. After chronic sympathetic denervation, the percentage of PKC $\beta$ I immunopositive neurons $(21.27 \pm 1.43 \%$, $\mathrm{n}=3, \mathrm{P}>0.05$ ) was unchanged with respect to that obtained in normal preparations $(18.38 \pm 2.53 \%, \mathrm{n}=4)$ (Fig 4, panel A). The percentage of $\mu$-opioid receptor-positive neurons expressing also PKC $\beta$ I immunoreactivity remained unchanged after chronic sympathetic denervation (normal: $41.38 \pm 3.09 \%, \mathrm{n}=4$; denervated: $37.62 \pm 9.05 \%, \mathrm{n}=3, \mathrm{P}>0.05$ ) (Fig 4, panel B).

The pattern of distribution of PKC $\beta$ II immunoreactivity was quite similar to that observed for PKC $\beta$ I. Myenteric neurons displayed a "speckled" staining of plasma membranes and cytoplasm (Fig 3, panel F) both in normal and sympathetically denervated preparations. However, with respect to PKC $\beta$ I labelling, PKC $\beta$ II staining was more diffused in the cytoplasm of myenteric neurons. PKC $\beta I$ immunoreactivity was present also in neuronal fibers within the myenteric plexus, in interganglionic strands and in the external muscle layer. Enteric glial cells were faintly stained for PKC $\beta I I$. Moreover, fibroblasts and erythrocytes in blood vessels displayed PKC $\beta I$ II immunoreactivity. Following chronic sympathetic denervation, the percentage of PKC $\beta$ II immunoreactive neurons was significantly reduced $(18.84 \pm 1.00 \%, \mathrm{n}=4 ; \mathrm{P}<0.01)$ with respect to that observed in normal 
preparations $(26.95 \pm 1.40 \%, \mathrm{n}=4)$ (Fig. 5). This latter value was significantly higher $(\mathrm{P}<0.05)$ than the percentage of myenteric neurons expressing PKC $\alpha, \beta I$ or $\gamma$ (Fig 4, panel A). The percentage of $\mu$-opioid receptor-positive neurons labelled for PKC $\beta I I$ was significantly lower in preparations obtained from denervated animals (normal: $54.49 \pm 6.82 \%, \mathrm{n}=4$; denervated: $28.75 \pm 5.05 \%, \mathrm{n}=4 ; \mathrm{P}<0.05)$. In normal preparations, the percentage of $\mu$-opioid receptorpositive neurons labelled for $\mathrm{PKC} \beta \mathrm{II}$ was significantly higher $(\mathrm{P}<0.05)$ than the percentage of $\mu$-opioid receptor-positive staining for PKC $\alpha, \beta \mathrm{I}$ or $\gamma$ and $\mu$-opioid receptor (Fig 4, panel B).

In colonic whole-mount preparations obtained from both normal and denervated animals, $\mathrm{PKC} \gamma$ antibody stained the cytoplasm of myenteric neurons and their processes both in myenteric ganglia and in interconnecting strands (Fig 3, panel H). PKC $\gamma$ immunoreactivity was also observed in ICC support cells at the periphery of myenteric ganglia and in blood vessels (erythrocytes). Enteric glial cells were not stained with anti-PKC $\gamma$ antibody. After chronic sympathetic denervation, the percentage of $\mathrm{PKC} \gamma$ positive neurons $(19.63 \pm 0.79 \%$, $\mathrm{n}=5)$ was not significantly different $(\mathrm{P}>0.05)$ from the value obtained in normal preparations $(22.36 \pm 1.61 \%, \mathrm{n}=4)$ (Fig. 4 panel A). The percentage of $\mu$-opioid receptor positive neurons displaying immunoreactivity for $\mathrm{PKC} \gamma$ was unchanged after chronic sympathetic denervation (normal: 30.55 $\pm 2.77 \%, \mathrm{n}=4$; denervated: $28.69 \pm 7.18 \%, \mathrm{n}=5$; $\mathrm{P}>0.05$ ) (Fig. 4 panel B).

\section{Discussion}

In the present study, experimental evidence has been provided to suggest that, in the myenteric plexus of the guinea-pig distal colon, $\mu$-opioid receptors are coupled to $\mathrm{Ca}^{++}-$ dependent PKCs. Such interaction may contribute to the development of adaptive changes involving opioid pathways after chronic ablation of the sympathoadrenergic pathways in this experimental model. Previous data obtained by means of functional and biochemical 
approaches have indirectly shown that $\mu$-opioid receptors may activate $\mathrm{Ca}^{++}$-dependent PKCs on myenteric cholinergic neurons in the guinea pig colon [27]. In view of the facilitatory effect exerted by PKC on acetylcholine overflow in our model, such regulation has been interpreted as a negative feedback mechanism aimed to attenuate $\mu$-opioid receptor-mediated inhibition of this functional parameter. In the present study, the ability of the $\mu$-opioid agonist, DAMGO, to enhance $\mathrm{Ca}^{++}$-dependent PKC activity in myenteric synaptosomes gives a direct indication for a positive coupling between $\mu$-opioid receptors and PKC in colonic myenteric neurons. Regulation of PKC activity by DAMGO occurs specifically through $\mu$-opioid receptors, since concomitant administration of the selective antagonist, CTAP, blocked the facilitatory effect of the opioid agonist. However, in the adopted experimental conditions, $\mu$ opioid receptors do not exert a tonic modulation on PKC activity in myenteric neurons, since CTAP, per se, did not exert any effect on this parameter. In agreement with our data, there are reports suggesting that $\mu$-opioid actions, both in the central and in the peripheral nervous systems, involve PKC stimulation, which may result from activation of PLC via pertussis toxin-sensitive $\mathrm{G}$ proteins $[26,34,35]$. The close correlation between $\mu$-opioid receptors and PKC in our model has been further demonstrated by immunohistochemical data indicating their co-localization with $\mathrm{Ca}^{++}$-dependent $\mathrm{PKC}$ isoforms in myenteric neurons. In good agreement with other studies describing the distribution of $\mu$-opioid receptors in different regions of the guinea-pig gut $[36,37]$, in the distal colon of the same species, $\mu$-opioid receptor immunoreactivity was confined to Dogiel Type I myenteric neurons which comprise ascending excitatory motor neurons to the muscle, descending inhibitory motor neurons and descending interneurons $[36,38]$. In particular, the presence of $\mu$-opioid receptors on ascending excitatory motor neurons, which are prevalently cholinergic, is consistent with the functional evidence that $\mu$-opioid receptors mediate inhibition of acetylcholine overflow as 
well as peristalsis in the guinea pig colon $[17,29]$. Concerning $\mathrm{Ca}^{++}$-dependent $\mathrm{PKC}$ isoforms distribution, our results indicate that all the four conventional PKC isoforms are expressed in myenteric neurons of the guinea pig colon. At variance with data obtained in the ileum of the same species, where $\mathrm{PKC} \gamma$ was the conventional $\mathrm{PKC}$ isoform more abundantly expressed in neurons [39], we found a higher percentage of PKC $\beta$ II-labelled myenteric neurons in the distal colon. This discrepancy might depend upon differences in the distribution of $\mathrm{Ca}^{++}$dependent PKC isoforms along the guinea pig gut, although differences in the methodology used and antibodies cannot be excluded. The higher degree of co-localization of PKC $\beta I I$ and $\mu$-opioid receptors found in normal preparations, suggests that the enteric $\mu$-opioidergic system may retain a predominant modulatory effect upon this $\mathrm{Ca}^{++}$-dependent $\mathrm{PKC}$ isoform. Following chronic sympathetic denervation, the coupling efficiency between $\mu$-opioid receptors and $\mathrm{Ca}^{++}$-dependent PKC in myenteric neurons seems to be reduced, as suggested by the inability of DAMGO to modulate PKC activity. This observation is in good agreement with functional evidences demonstrating that PKC antagonists lose their ability to enhance $\mu$ opioid agonist-mediated inhibition of acetylcholine overflow in the sympathetically denervated colon [27]. Different hypotheses may be put forward to explain the development of this change, including alterations in the coupling between $\mu$-opioid receptors and signal transduction G proteins involved in PLC activation [29], or a decreased efficiency of PKC after chronic ablation of the inferior mesenteric ganglion. In line with this latter hypothesis, $\mathrm{Ca}^{++}$-dependent PKC activity significantly decreased in myenteric synaptosomes obtained from denervated colonic specimens. Accordingly, development of subsensitivity to the facilitatory effect of phorbol esters on acetylcholine overflow as well as reduced expression levels of $\mathrm{Ca}^{++}$-dependent PKC, were previously observed in these experimental conditions [27]. Changes in PKC activity and expression after chronic interruption of neuronal pathways 
have already been demonstrated in different models both in the central and in the peripheral nervous systems [40-42]. From a functional viewpoint, an impairment within the $\mu$-opioid receptor/Ca ${ }^{++}$-dependent PKCs cascade, after chronic sympathetic denervation, may be implicated in the development of supersensitivity to the inhibitory effect of $\mu$-opioid agents on the enteric cholinergic function [29]. In these conditions the negative feedback provided by PKC on $\mu$-opioid action would be lost, thus allowing a more sustained opioidergic-mediated inhibitory effect on cholinergic neurons. A functional consequence of this latter effect is a higher $\mu$-opioid receptor-mediated inhibition of the peristaltic reflex in the denervated colon [17]. With this regard it is noteworthy underlying that, although the extrinsic inhibitory sympathetic input to the guinea pig distal colon exerts a physiologically relevant tonic modulation on enteric cholinergic neurons, some functional parameters such as acetylcholine release and peristalsis remain unchanged after long term suppression of the sympathoadrenergic pathways [43]. These observation are highly suggestive of the occurrence of adaptive changes involving an increased functional relevance of nonadrenergic inhibitory systems, such as the opioidergic intrinsic pathways, in order to restore intestinal motility after chronic ablation of the extrinsic sympathetic input [16].

Alterations in the $\mu$-opioid receptor/ $\mathrm{Ca}^{++}$-dependent PKCs cascade after chronic sympathetic denervation may involve specific $\mathrm{Ca}^{++}$-dependent $\mathrm{PKC}$ isoforms, as suggested by the decreased expression levels of PKC $\beta \mathrm{I}, \beta \mathrm{II}$ and $\gamma$, but not of PKC $\alpha$, in myenteric synaptosomes obtained from sympathetically denervated animals. Reduced PKC expression may cause an impaired translocation of the enzyme into the plasma membrane from the cytosol, resulting in abnormal activation and, consequently, in altered phosphorylation of substrate proteins [44]. Immunohistochemical findings have provided some indications suggesting that, in our model, neuronal PKC $\beta$ II may undergo more drastic changes after 
chronic sympathetic denervation. In fact, in these conditions, the percentage of neurons immunopositive for PKC $\beta$ II, but not for PKC $\alpha, \beta \mathrm{I}$ and $\gamma$, significantly decreased, suggesting either a reduced rate of synthesis or an enhanced rate of degradation of the isoform, in these experimental conditions. This latter change also reflects a reduced percentage of $\mu$-opioid receptor-positive neurons expressing PKC $\beta I I$. Overall, these observations suggest a more central role for PKC $\beta I I$ in the impairment of the $\mu$-opioid receptor/ conventional PKCs pathway in denervated preparations. In good agreement with these observations, in the rat hippocampus, adaptive changes underlying neuronal reorganization after cholinergic denervation entailed a selective reduction of PKC $\beta$ at membrane level [42]. In contrast to data obtained for PKC $\beta \mathrm{I}, \beta \mathrm{II}$ and $\gamma, \mathrm{PKC} \alpha$ levels increased after chronic sympathetic denervation. This last change is in accordance with reports documenting augmented activity and expression of $\mathrm{Ca}^{++}$-dependent PKC isoforms after neuronal deafferentation which may be correlated with neurogenesis and synaptic plasticity [41, 45]. Up-regulation of PKC in myenteric neurons, which causes phosphorylation of different targets including opioid receptors, Gi/o proteins and adenylate cyclase, has been widely documented also during adaptive changes subserving development of tolerance and dependence to opioids [46, 35]. Increased PKC $\alpha$ expression in myenteric colonic ganglia after chronic sympathetic denervation might reflect an attempt to compensate the loss of the other PKCs thus maintaining neuronal homeostasis, although such change would exclude the involvement of this isoform in the development of supersensitivity to $\mu$-opioid agonists, at least in these experimental conditions. Noteworthy, as already observed in the guinea pig ileum [39], PKC $\alpha$ staining was particularly intense in colonic enteric glial cells, which play not only a structural and supportive role in the ENS, but may also participate to adaptive changes aimed to maintain the local neuronal environment [16]. 
Differences in structure, biochemical properties and tissue distribution of various PKC isoenzymes may account for distinct cellular functions $[21,22]$. The dissimilar regulation of expression of specific $\mathrm{Ca}^{++}$-dependent $\mathrm{PKC}$ isoforms after chronic sympathetic denervation is in line with the standpoint that, at the intestinal level, diverse PKC isoforms may retain specific and distinct modulatory roles both on the secretory and motor function by regulating the activity of different cell populations of the enteric microenvironment including neurons, glial cells, smooth muscle and epithelial cells [39, 47].

\section{Conclusions}

In the present study, direct evidence has been provided to indicate that in the myenteric plexus of the guinea-pig distal colon $\mu$-opioid receptors exert a facilitatory action on $\mathrm{Ca}^{++}$-dependent PKC activity. After chronic sympathetic denervation, the opioidergic modulatory effect on PKC is no more evident, apparently as a consequence of a reduced efficiency of the enzyme. The blunting of this molecular cascade seems to involve principally PKC $\beta I I$, although $\beta I$ and $\gamma$ isoforms may also participate, whereas $\mathrm{PKC} \alpha$, which is predominantly located on enteric glial cells, seems to be excluded.

\section{Acknowledgements}

The authors wish to thank Professor Carlo Capella, Director of the Surgical Pathology, Department of Human Morphology, for the kind support provided for the execution of the immunohistochemistry experiments. Dr. Marcella Reguzzoni (Laboratory of Human Morphology, University of Insubria, Varese, Italy) for the excellent assistance in performing the electron microscope analysis of myenteric plexus synaptosomal preparations and Dr 
1 


\section{References}

[1] Greenwood-Van Meerveld B, Gardner CJ, Little PJ, Hicks GA, Dehaven-Hudkins DL. Preclinical studies of opioids and opioid antagonists on gastrointestinal function. Neurogastroenterol Motil 2004; 16 (suppl. 2); 46-53.

[2] Stefano GB, Goumon Y, Casares F, Cadet P, Fricchione GL, Rialas C, et al. Endogenous morphine. Trends Neurosci 2000; 23: 436-42.

[3] Waldhoer M, Barlett SE, Whistler JL. Opioid receptors. Annu Rev Biochem 2004; 73: $953-90$.

[4] Van Bockstaele, EJ. Morphological substrates underlying opioid, epinephrine and $\gamma$ aminobutyric acid inhibitory actions in the rat locus coeruleus. Brain Res Bull 1998; 47: $1-15$.

[5] Limberger N, Späth L, Hölting T, Starke K. Mutual interaction between presynaptic $\alpha_{2}$-adrenoceptors and opioid $\kappa$-receptors at the noradrenergic axons of rabbit brain cortex. Naunyn-Schmiedeberg's Arch Pharmacol, 1986; 334: 166-71.

[6] Schoffelmeer ANM, Putters J, Mulder AH. Activation of presynaptic $\alpha_{2}$ adrenoceptors attenuates the inhibitory effect of $\mu$-opioid receptor agonists on noradrenaline release from brain slices. Naunyn-Schmiedeberg's Arch Pharmacol 1986; 333: 377-80.

[7] Allgaier C, Daschman B, Sieverling J, Hertting G. Presynaptic א- opioid receptors on noradrenergic nerve terminals couple to G proteins and interact with the $\alpha_{2}$ adrenoceptors. J Neurochem 1989; 53: 1629-35. 
[8] Horváth G, Szikszay M, Benedek G. Potentiated hypnotic action with a combination of fentanyl, a calcium channel blocker and an alpha2-agonist in rats. Acta Anaesthesiol Scand 1992; 36: 170-4.

[9] Ossipov MH, Lopez Y, Bian D, Nichols ML, Porreca F. Synergistic antinociceptive interactions of morphine and clonidine in rats with nerve-ligation injury. Anesthesiology 1997; 86: 196-204.

[10] Stone LS, MacMillan LB, Kitto KF, Limbird LE, Wilcox GL. The $\alpha_{2 A}$-adrenergic receptor subtype mediates spinal analgesia evoked by $\alpha_{2}$ agonists and is necessary for spinal adrenergic-opioid synergy. J Neurosci 1997;17: 7157-65.

[11] Ulibarri I, García-Sevilla JA, Ugedo L. Modulation of brain alpha 2-adrenoceptor and mu-opioid receptor densities during morphine dependence and spontaneous withdrawal in rats. Naunyn-Schmiedeberg's Arch Pharmacol, 1987; 336: 530-37.

[12] Karunanithi S, Lavidis NA. Effect of chronic morphine treatment on $\alpha_{2}$-adrenoceptor mediated autoinhibition of transmitter release from sympathetic varicosities of the mouse vas deferens. Br J Pharmacol 2001; 132: 403-10.

[13] Taylor DA, Leedham JA, Doak N, Fleming WW. Morphine tolerance and nonspecific subsensitivity of the longitudinal muscle myenteric plexus preparation of the guineapig to inhibitory agonists. Naunyn-Schmiedeberg's Arch Pharmacol 1988; 338: 55359.

[14] Johnson SM. Nonspecific tolerance in ileal circular muscle-myenteric plexus preparations from morphine-pretreated guinea pigs. J Pharmacol Exp Ther 1991; 257: $239-46$.

[15] Leedham JA, Kong JQ, Taylor DA, Johnson SM, Fleming WW. Membrane potential in myenteric neurons associated with tolerance and dependence to morphine. $\mathrm{J}$ Pharmacol Exp Ther 1992; 263: 15-9. 
[16] Giaroni C, De Ponti F, Cosentino M, Lecchini S, Frigo GM. Plasticity in the enteric nervous system. Gastroenterology 1999a; 117:1438-58.

[17] Giaroni C, Somaini L, Marino F, Cosentino M, Senaldi A, De Ponti F, et al. Modulation of enteric cholinergic neurons by hetero- and autoreceptors: cooperation among inhibitory inputs. Life Sci 1999b; 65: 813-21.

[18] Fiorillo CD, Williams JT. Opioid desensitization: interactions with G-protein-coupled receptors in the locus coeruleus. J Neurosci 1996;16: 1479-85.

[19] Jordan BA, Gomes I, Rios C, Filipovska J, Devi LA. Functional interactions between $\mu$ opioid and $\alpha_{2 \mathrm{~A}}$-adrenergic receptors. Mol Pharmacol 2003; 64: 1317-24.

[20] Nishizuka Y. Discovery and prospect of protein kinase C research: epilogue. J Biochem 2003;133: 155-58.

[21] Amadio M, Battaini F, Pascale A. The different facets of protein kinases C: old and new players in neuronal signal transduction pathways. Pharmacol Res 2006; 54: 317 25.

[22] Sossin WS. Isoform specificity of protein kinase Cs in synaptic plasticity. Learn Mem 2009; 14: 236-46.

[23] Newton AC. Regulation of the ABC kinases by phosphorylation: protein kinase $\mathrm{C}$ as a paradigm. Biochem J 2003; 370: 361-71.

[24] Ueda H, Miyamae T, Fukushima N, Takeshima H, Fukuda K, Sasaki Y, et al. Opioid $\mu$ - and $\kappa-$-receptor mediate phospholipase C activation through Gi1 in Xenopus oocytes. Mol Brain Res 1995; 32: 166-70.

[25] Kramer HK, Simon EJ. Role of protein kinase C (PKC) in agonist-induced $\mu$-opioid receptor down-regulation: II. Activation and involvement of the $\alpha, \varepsilon$, and $\zeta$ isoforms of PKC. J. Neurochem. 1999; 72: 594-604. 
[26] Bailey CP, Llorente J, Gabra BH, Smith FL, Dewey WL, Kelly E, et al. Role of protein kinase $\mathrm{C}$ and $\mu$-opioid receptor (MOPr) desensitization in tolerance to morphine in rat locus coeruleus neurons. Eur J Neurosci 2009; 29: 307-18.

[27] Zanetti E, Giaroni C, Vanti A, Canciani L, Giuliani D, Lecchini S, et al. Involvement of protein kinase $\mathrm{C}$ in the adaptive changes of cholinergic neurons to sympathetic denervation in the guinea pig myenteric plexus. Life Sci 2003; 73: 2641-54.

[28] Mazzanti L, Del Tacca M, Breschi MC, Frigo GM, Friedman C, Crema A. The time course of functional and morphological changes of the guinea-pig colon after "a frigore" denervation of the periarterial sympathetic nerves. Acta Neuropathol 1972; 22(3): 190-9

[29] Giaroni C, Zanetti E, Vanti A, Canciani L, Lecchini S, Frigo GM. Sympathetic denervation-induced changes in $\mathrm{G}$ protein expression in enteric neurons of the guinea pig colon. Life Sci 2002; 71: 1961-73.

[30] Bradford MM. A rapid and sensitive method for the quantitation of microgram quantities of protein utilizing the principle of protein-dye binding. Anal Biochem $1976 ; 72: 248-54$

[31] Pascale A, Noguès X, Marighetto A, Micheau J, Battaini F, Govoni S, et al. Cytosolic hippocampal PKC and aging: correlation with discrimination performance. Neuroreport 1998; 9: 725-29.

[32] Amadio M, Scapagnini G, Lupo G, Drago F, Govoni S, Pascale A. PKCbetaII/HuR/VEGF: a new molecular cascade in retinal pericytes for the regulation of vegf gene expression. Pharmacol Res 2008; 57: 60-6.

[33] Toole L, Belai A, Burnstock G. A neurochemical characterization of the golden hamster myenteric plexus. Cell Tissue Res 1998; 291: 385-94. 
[34] Chakrabarti S, Regec A, Gintzler AR. Chronic morphine acts via a protein kinase C $\gamma$ G $\beta$-adenylyl cyclase complex to augment phosphorylation of G $\beta$ and G $\beta \gamma$ stimulatory adenylyl cyclase signaling. Mol Brain Res 2005; 138: 94-103.

[35] Liu JG, Anand KJS. Protein kinases modulate the cellular adaptations associated with opioid tolerance and dependence. Brain Res Rev 2001; 38: 1-19.

[36] Ho A, Lievore A, Patierno S, Kohlmeier SE, Tonini M, Sternini C. Neurochemically distinct classes of myenteric neurons express the $\mu$-opioid receptor in the guinea pig ileum. J Comp Neurol 2003; 458: 404-11.

[37] Sternini C, Patierno S, Selmer IS, Kirchgessner A. The opioid system in the gastrointestinal tract. Neurogastroenterol Motil 2004; 16 (Suppl. 2): 3-16.

[38] Lomax AE, Furness JB. Neurochemical classification of enteric neurons in the guineapig distal colon. Cell Tissue Res 2000; 302: 59-72.

[39] Poole DP, Hunne B, Robbins HL, Furness JB. Protein kinase C isoforms in the enteric nervous system. Histochem Cell Biol 2003; 120: 51-61.

[40] Akhtar RA, Abdel-Latif AA. Surgical sympathetic denervation increases alpha 1adrenoceptor-mediated accumulation of myo-inositol trisphosphate and muscle contraction in rabbit iris dilator smooth muscle. J Neurochem 1986; 46: 96-104.

[41] Ayyagari PV, Harrell LE, Parsons DS, Kolasa K. Sympathetic sprouting reverses decreases in membrane-associated activity of protein kinase $\mathrm{C}$ following septohippocampal denervation of the rat hippocampus. Brain Res 1996; 708: 205-8.

[42] Kolasa K, Parsons DS, Harrell LE. Effect of phospholipase C and protein kinase C following cholinergic denervation and hippocampal sympathetic ingrowth in rat hippocampus. Neurosci 2000; 99: 25-31.

[43] Frigo GM, Lecchini S, Marcoli M, Tonini M, D’Angelo L, Crema A. Changes in sensitivity to the inhibitory effects of adrenergic agonists on intestinal motor activity 
after chronic sympathetic denervation. Naunyn Schmiedeberg's Arch Pharmacol 1984; 325: $145-52$.

[44] Pascale A, Amadio M, Govoni S, Battaini F. The aging brain, a target key for the future: the Protein Kinase C involvement. Pharmacol Res 2007; 55: 560-69.

[45] Sneddon AA, Delday MI, Maltin CA. Amelioration of denervation-induced atrophy by clenbuterol is associated with increased PKC-alpha activity. Am J Physiol Endocrinol Metab, 2000; 279: E188-95.

[46] Chakrabarti S, Gintzler AR. Phosphorylation of G $\beta$ is augmented by chronic morphine and enhances G $\beta \gamma$ stimulation of adenylyl cyclase activity. Mol Brain Res 2003; 119 : 144-51.

[47] Furness JB, Hind AJ, Ngui K, Robbins HL, Clerc N, Merrot T, et al. The distribution of PKC isoforms in enteric neurons, muscle and interstitial cells of the human intestine. Histochem Cell Biol 2006; 126: 537-48. 


\section{Legends to figures}

Fig. 1. Facilitatory effect of the $\mu$-opioid receptor agonist, DAMGO on $\mathrm{Ca}^{++}$-dependent PKC activity in myenteric plexus synaptosomes of the guinea pig distal colon obtained from normal (hatched columns) and sympathetically denervated animals (black columns) in the absence and in the presence of the antagonist, CTAP. Each column represents the mean of 6-9 experiments. Vertical bars indicate SEM; ${ }^{* * *} \mathrm{P}<0.001$ (vs. control by one sample $\mathrm{t}$ test), ${ }^{\#} \mathrm{P}<0.01,{ }^{\#} \mathrm{P}<0.05$ (vs. agonist alone in normal preparations) by one way ANOVA followed by Dunnett's post hoc test.

Fig. 2. Representative Western blottings of PKC $\alpha, P K C \beta I, P K C \beta I I$ and PKC $\gamma$ and $\alpha$-tubulin in myenteric plexus enriched synaptosomal preparations of the guinea pig distal colon obtained from normal and sympathetically-denervated animals. $\mathbf{N}=$ normal animals; $\mathbf{D}=$ sympathetically-denervated animals.

\section{Fig 3.}

Immunohistochemical co-localisation of $\mathrm{Ca}^{++}$-dependent $\mathrm{PKC}$ isoforms with $\mu$-opioid receptor in whole-mount preparations of guinea pig distal colon. A-B): Myenteric ganglion showing a neuron with plasma membrane and cytoplasmic labelling for $\mu$-opioid receptor (A) and a diffuse cytosolic staining for PKC $\alpha$ (B). PKC $\alpha$ immunoreactivity was evident also in glial cells (arrowhead) surrounding the co-marked neuron. C-D): Myenteric plexus neuron with diffused cytoplasmatic labelling for $\mu$-opioid receptor (C, arrow) and for PKC $\beta I$ (D, arrow). In the same ganglion, neuronal fibers were stained for $\mu$-opioid receptor (arrowhead). E-F): Myenteric ganglion showing neuronal fibers stained for $\mu$-opioid receptor (arrowhead) and neurons with diffused cytoplasmatic labelling for $\mu$-opioid receptor (E, arrow) and for 
PKC $\beta I I(F$, arrow). G-H): Myenteric ganglion showing neurons with cytoplasmic staining for $\mu$-opioid receptor only (G, arrowhead) and for both $\mu$-opioid receptor $(G$, arrow) and PKC $\gamma(\mathrm{H}$, arrow). Magnification for each plate was $1000 \mathrm{x}$.

\section{Fig. 4.}

(A) Percentage of myenteric neurons staining for $\mathrm{Ca}^{++}$-dependent $\mathrm{PKC}$ isoforms in guinea pig distal colon whole-mount preparations obtained from normal (empty columns) and sympathetically denervated animals (hatched columns). (B) Percentage of positive $\mu$-opioid receptor myenteric neurons staining for $\mathrm{Ca}^{++}$-dependent $\mathrm{PKC}$ isoforms in guinea pig distal colon whole-mount preparations obtained from normal (empty columns) and sympathetically denervated animals (hatched columns). Each column represents the mean of 3-5 experiments. Vertical bars indicate SEM; ${ }^{* * *} \mathrm{P}<0.001$ (vs. \% of PKC $\beta I$ positive neurons in normal preparations), ${ }^{* *} \mathrm{P}<0.01$ (vs. $\%$ of $\mu$-opioid receptor positive neurons staining for PKC $\beta I$ in normal preparations), by Student's t test; ${ }^{\#} \mathrm{P}<0.05$ (A: \% of PKC $\beta I I$ vs. PKC $\alpha, \beta$ I and $\gamma$ positive neurons in normal preparations; B: $\%$ of $\mu$-opioid receptor positive neurons staining for PKC $\beta$ II vs. PKC $\alpha, \beta$ I and $\gamma$ in normal preparations), by one way ANOVA followed by Dunnett's post hoc test.

\section{Fig. 5.}

Guinea pig distal colon longitudinal muscle myenteric plexus whole-mount preparations obtained from normal (A) and denervated (B) animals, showing neurons immunostained for PKC $\beta$ II. Magnification for each plate was $400 \mathrm{x}$. 
Table 1

Primary antisera and their respective dilutions used for Western Blot (WB) assay and immunohistochemistry (HC).

\begin{tabular}{|c|c|c|c|c|c|}
\hline ANTISERUM & $\begin{array}{c}\text { Dilution } \\
\text { (WB) }\end{array}$ & $\begin{array}{c}\text { Dilution } \\
\text { (HC) }\end{array}$ & Source & Host & Code \\
\hline $\mathrm{PKC} \alpha$ & $1: 2000$ & & Santa Cruz Biotech (Santa Cruz CA) & Rabbit & sc-208 (C-20) \\
\hline $\mathrm{PKC} \alpha$ & $\underline{-}$ & $1: 100$ & Santa Cruz Biotech & Mouse & sc-8393 (H-7) \\
\hline PKC $\beta \mathrm{I}$ & $1: 500$ & $1: 400$ & Santa Cruz Biotech & Mouse & sc-8049 (E-3) \\
\hline PKC $\beta I I$ & $1: 2500$ & & Santa Cruz Biotech & Rabbit & sc-210 (C-18) \\
\hline PKC $\beta I I$ & $\longrightarrow$ & $1: 500$ & Santa Cruz Biotech & Mouse & sc-13149 (F-7) \\
\hline $\mathrm{PKC} \gamma$ & $1: 200$ & $1: 100$ & Zymed Lab (San Francisco, CA) & Mouse & 13-3800 (PKC66) \\
\hline$\mu$-opioid receptor & $\longrightarrow$ & $1: 1500$ & Abcam (Cambridge, MA) & Rabbit & Abcam 10275 \\
\hline$\alpha$-tubulin & $1: 1000$ & $\longrightarrow$ & Sigma-Aldrich (Milano, Italy) & Mouse & T-6199 (DM-1A) \\
\hline
\end{tabular}


Fig. 1

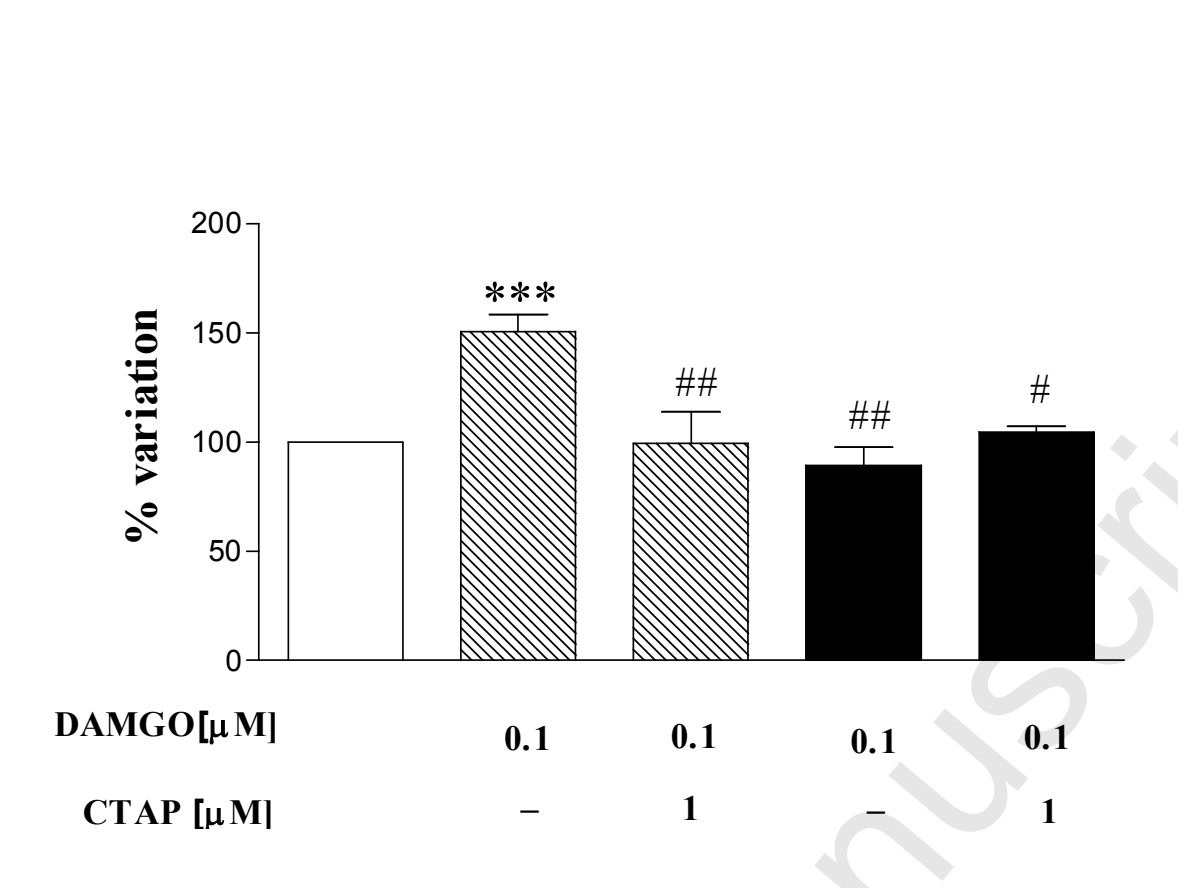

CTAP $[\mu \mathrm{M}]$

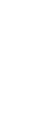


Fig. 2
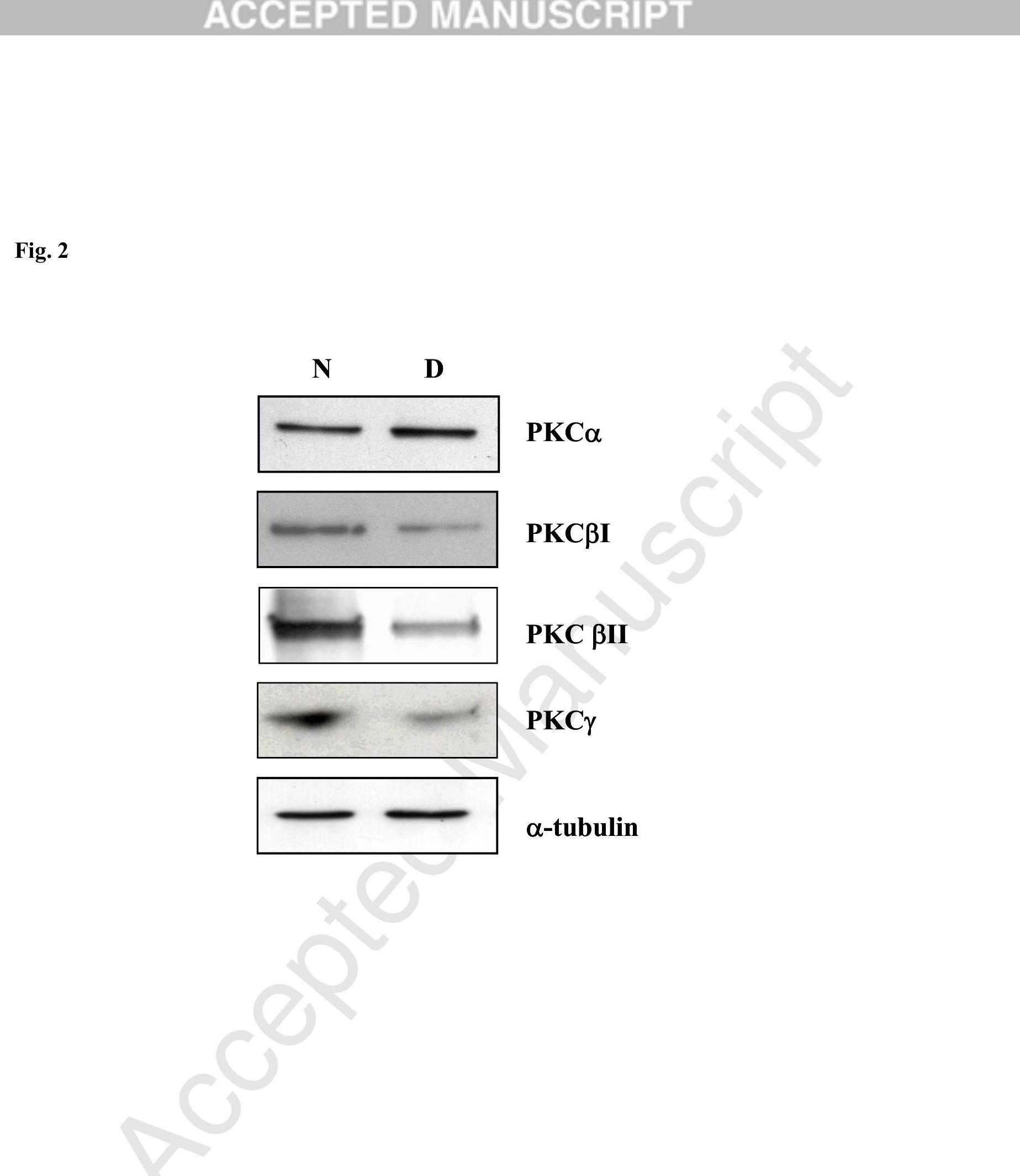

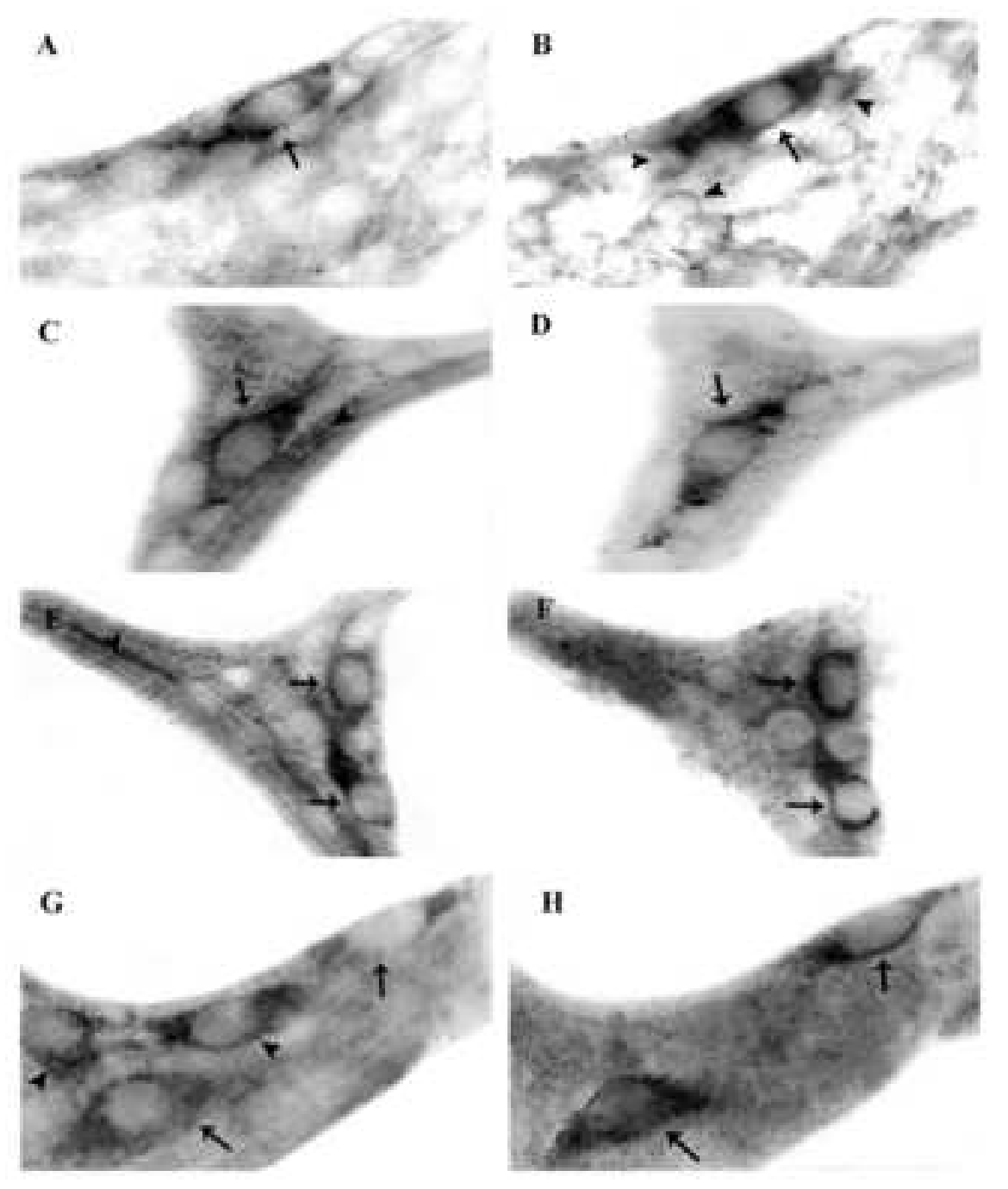

更

Figure ACCEPTED MANUSCRIPT
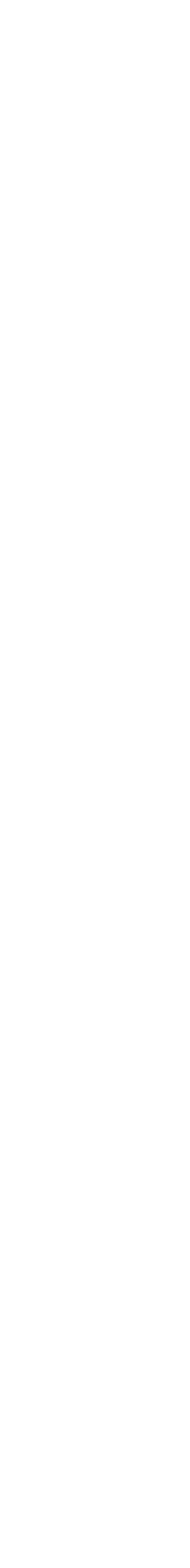
Fig. 4
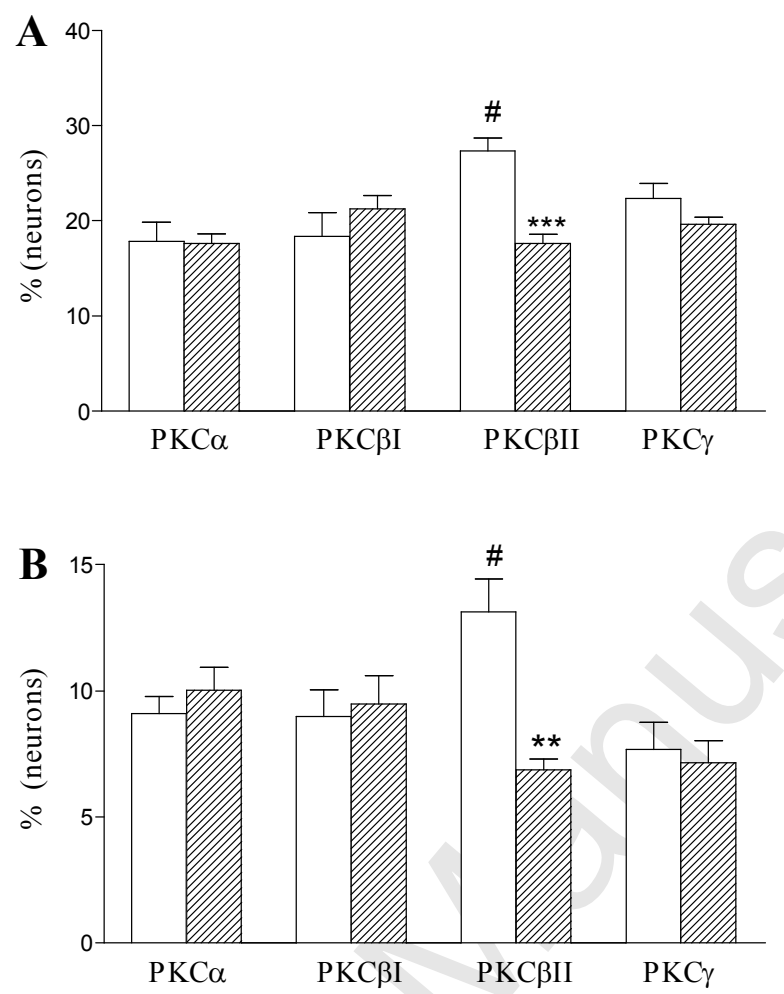

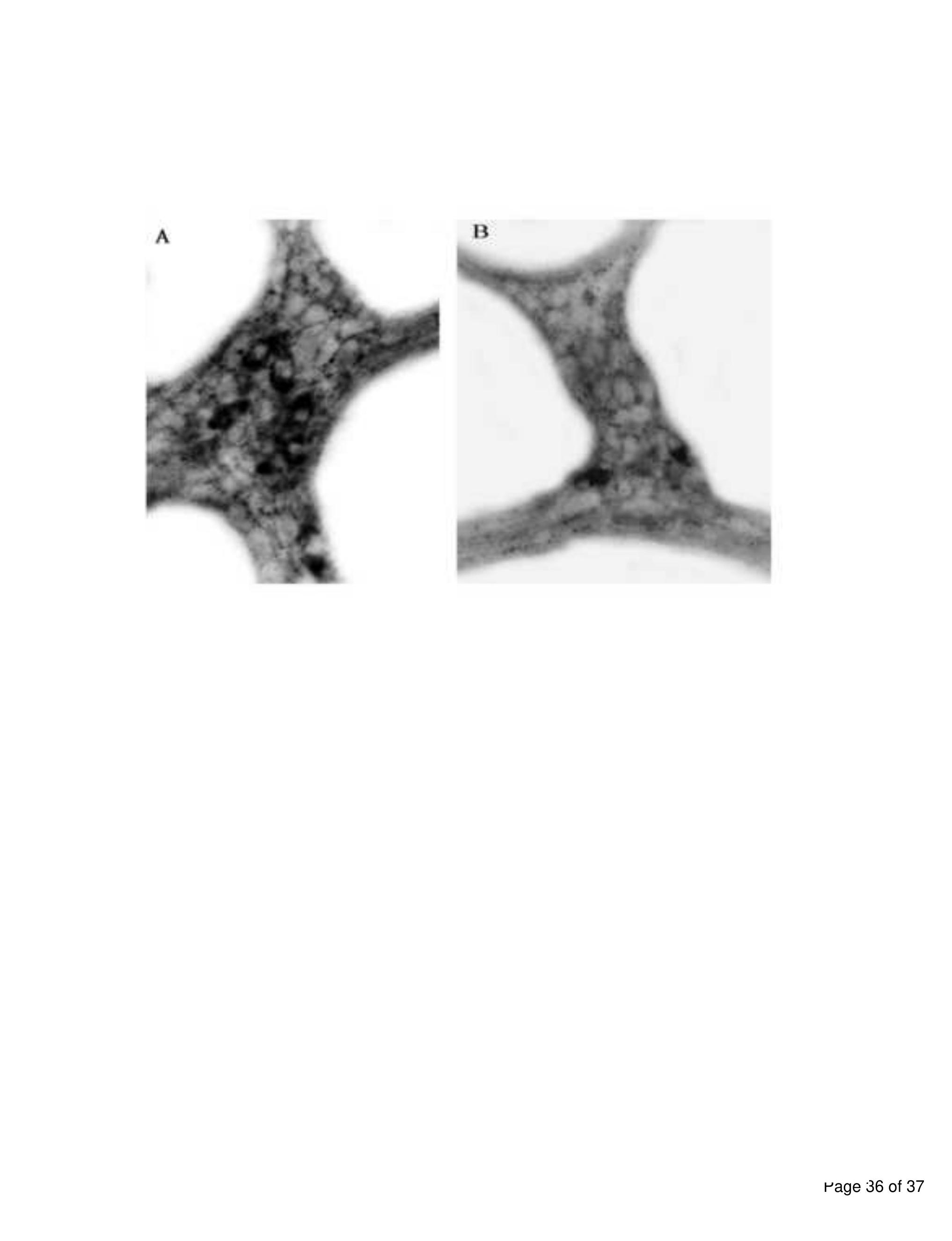

rage 36 of 37

.

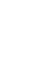



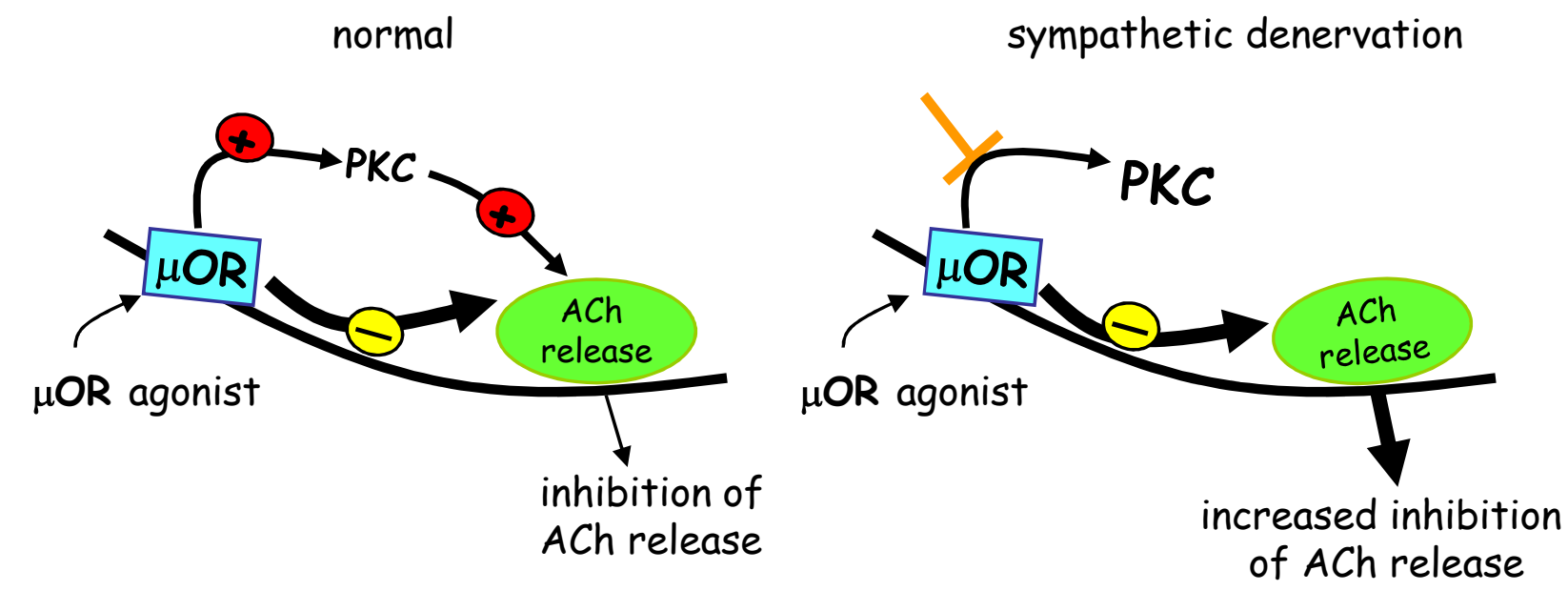

$\mu$-opioid receptors uncoupling to PKC in the guinea pig colon myenteric plexus underlays development of supersensitivity to the inhibitory effect of $\mu$-opioid agonists on acetylcholine release after chronic sympathetic denervation 